\title{
Current Status of the Nigerian Aqua Feeds Industry: A Review
}

\author{
Udo, I. U., Umanah, S. I.
}

Department of Fisheries and Aquatic Environmental Management, University of Uyo, Uyo, Nigeria.

\begin{abstract}
Nigeria, with a population of about 175,000,000 people is grossly undernourished; lack of adequate protein being the primary factor. Currently, the Nigerian aqua feeds industry is experiencing rapid growth. However, production capacity cannot match the ever increasing aquaculture production thereby resulting in a whopping 75 percent importation of the total aqua feeds required by the fish farmers in Nigeria. Admittedly, this problem needs urgent attention. With this in mind, the authours have reviewed the importance of fish in human nutrition to buttress the superiority of fish protein over all other protein and why fish demand always outpace supply. Overview of the aquaculture production is also presented to compare fish demand and supply alongside the ever increasing population in order to establish deficit. Past and current status of the Nigerian aqua feeds industry is also reviewed and the established trend indicated that while there was a dwindling production capacity in the 1980s, a sharp increase was noticedin 2000 when production capacity of 35,570 tonnes of aqua feeds was recorded while production stood at 10,760 tonnes.In 2015, Nigeria is estimated to have produced 647,750 metric tonnes of aqua feeds. A review of the supply analysis indicated that Nigeria still needs to step up local production in order to reduce importation. The last section of this review deals with the challenges faced by the Nigeria aqua feed industry with lack of feed ingredients taking the lead. Indirect devaluation of naira has been seen to have a serious negative impact on the prices of ingredients used to manufacture these aqua feeds as well as, inadequate supply of maize and soybean, which are also competed for by humans and livestocks. From this review, it is seen that there is an urgent need for Nigeria to step up aqua feeds production if Nigeria must attain self-sufficiency in terms of fish production. The solution to it is for government to provide assistance to the agricultural sector by earmarking a better percentage of the country's budget for people to do commercial agriculture. Incentives should also be made available on areas like fish nutrition, processing and feed formulation in order to encourage the youths in becoming experts in this fields.
\end{abstract}

Keywords: aquafeed, feedstuff, fishmeal, maize, soybean, self-sufficiency.

\section{INTRODUCTION}

Nigeria, having a population growth rate of 2.38 percent (2008 estimate) and projected population of $206,165,946$ in 2025 (2025 estimate)is not adequately supplied with protein, which is one of the basic parts of our daily diet (FAO, 2014). According to Central Bank of Nigeria (CBN, 2016), beef per capita per annum in Nigeria is about two kilogrammes while egg is about four kilogrammes. Local milk production is also inadequate when compared with the current population of about 180 million people. For instance, in 2010, about 0.5 million metric tons of milk were produced in Nigeria, 0.57 in 2013 and since then the production rate has stagnated. Average yield remained at approximately 0.8 litres/cow/day over the past decadeThe country therefore is dependent on importation to meet up with the 1.45 billion litres estimated national milk requirement. Egg production of 10.3 billion per annum is not enough when compare with the current population. The same scenario is seen in fish production. According to the Nigeria fishery statistics - 2016 Summary report, the total fish demand for Nigeria calculated on the basis of the current population structure is $3.32 \mathrm{~m} \mathrm{Mt}$ while domestic production from Aquaculture, Artisanal and Industrial fisheriesstood at $1.123 \mathrm{~m}$ Mt. This shows a deficit of $2.197 \mathrm{~m}$ Mt. From all indications, an average Nigerian is malnourished with regards to protein and essential amino acids intake. In order to ameliorate this problem, all hands must be on deck among the stakeholders in term of improved production of all the aforementioned protein based agricultural products so that they will be available and affordable to average Nigerians.

Feed production and quality is considered to be one of the major factors influencing the success of fish production in aquaculture. According to finding, feed constituteup to 60 percent of total operational costs in aquaculture production (Ozigbo, et al., 2014). Unfortunately, this percentage contribution is going higher as aqua feeds industry is hamstrung by many challenges including lack of 
feed ingredients and lack of trained personnel.The objective of this work is to present an overview of why fish is needed more than any other protein source by humans and why aquaculture should be given more attention, present useful information on the status of fish production vis-à-vis past and current status of aqua feed production. Supply analysis of aqua feed is also presented while challenges facing the Nigerian aqua feeds industry and the way out are also x-rayed.

\section{THE IMPORTANCE OF FiSH IN HUMAN NUTRITION}

Over the years, humans have used fish protein as a food source. Besides, many health benefits are associated with eating fish. For example, fish and shellfish are richsources of omega-3 fatty acids Docosahexaenoic acid (DHA) and eicosapentaenoic acid (EPA). These two anti-inflammatory omega-3 fatty acids are readily needed by the body (Ruxton et al., 2004). Any species of wild-caught salmon either fresh or canned, sardines, albacore tuna, trout or mackerel has over 500mg of DHA plus EPA per 3.5 ounce serving. Those with moderate amount $(150 \mathrm{mg}-500 \mathrm{mg}$ per $3.5 \mathrm{oz}$ serving) include haddock, cod, hake, halibut, shrimp, sole, flounder, perch, bass, oysters, crab and farmed salmon).According to Djoussé et al. (2012), intake of marine omega-3 fatty acids is associated with lower risk of heart failure.Research also shows thatfish may increase grey matter in the brain and protect it from age-related deterioration (Raji et al., 2014).

Eating of fish can also help humans to overcome depression and become happier persons (Hallahan, 2007).Fish is also a very rich source of vitamin D. Some Fat-loaded fish like salmon and herring contain the highest amounts of vitamin D (Malesa-Ciećwierz and Usydus 2015). According to these authours, a single 4 ounces which is equivalent to 113 grams serving of cooked salmon has about 100 percent of the recommended intake of vitamin D.Fish is also a very good source of other vitamins such as vitamins A and B complex. Macular degeneration, also known as age-related macular degeneration (AMD or ARMD), a medical condition which may result in blurred or no vision in the center of the visual field is a major cause of blindness globally (Lim et al., 2012). According to Augood et al. (2008) consumption of oily fish at least once per week is linked to a 50 percent reduction of the odd ratios for neovascular age-related macular degeneration and therefore protects our vision during old age.Eating fish is also associated with reduced risk of autoimmune diseases, such as type 1 diabetes in both children and adults, rheumatoid arthritis and multiple sclerosis (Löfvenborg, 2014; Bäärnhielm, 2014). According to Yang et al. (2013) regular intake of fish and fish oils is related with a $24 \%$ lower risk of asthma in children. Research has shown fish may also improve sleep quality and it is delicious and easy to prepare (Hansen et al., 2014). Fish is also rich in fluoride, iodine, zinc, and iron. It is also an excellent source of selenium which is incorporated into a number of enzymes in the body, such as glutathione peroxidase. Glutathione peroxidaseplays a significant role in cell membrane protection from damage by free radicals, associated with increased risk of heart disease and cancer. The enzyme binds free radicals, makes them innocuous and thereby helps to protect our body against heart disease and certain cancers of different parts of the body.

\subsection{Fish Demand Versus Supply}

The awareness that fish is among the healthiest foods around the globe,coupled with the increase in human populationhas resulted in an increase in demand for fish and fish oil. Report had it thatabout 40 percent increase in fish demand has been recorded between 2000 and 2015 while about 35 percent increase in deficit over same period was anticipated (FDF, 2008). With the current consumption rate of over 1.5 million tons of fish per annum (CBN 2016) there is still a wide gap between demand and supply which must be filled if Nigeria is to achieved food security. Small and medium scale enterprises (SMEs) when combined with artisanal fisheries contribute about 82 percent of the domestic fish production. However, as catch from the wild is dwindling, aquaculture remains the only alternate source of fish and other aquatic products for human consumption. Globally, the projected fish supply from fish farming stood at 50 percent by 2020 . This trend provides an impetus to intensive fish farming in Nigeria strongly supported by a viable aqua feeds industry (EDR, 2014).

\section{Overview of Aquaculture Production in Nigeria}

Notwithstanding that the Nigerian aquaculture industry is about 50 years old (Olagunju, et al., (2007), yet the country has not been able to meet domestic production demand for the populace (Table 1). Regarding her potentials, Itaet al., (1985) in their survey reported that the country has about 13 million hectares of cultivable waters which could be harnessed for aquaculture production. A good number of cultivable fish species both exotic and indigenous have also been documented (Ngueku, 
2015).Among the numerous cultivable fish species in Nigerian a significant breakthrough in terms of seed production and new culture technology have been achieved in catfishes of the genera Clarias and Heterobranchus.They are the most commonly farmed fish(about 90 percent) andmost every national investment in aquaculture has been tailored towards it development. According to a recent review by Francis and Davies (2014) some marine species such as Tilapia guineensis, Sarotherodonmelanotheron, Pseudotolithus spp. (the croakers), Lutjanus spp. (the snappers) and Epinephelus (the groupers) etc. are now good candidates for aquaculture practice in Nigeria. The is no gainsaying the fact that Nigeria is potentially fit to produce fish to meet the rapidly growing population provided that aqua feeds production is given very serious attention.In recent years, a swift growth of this industry has been reported by many researchers (World Bank, 2013; Little et al., 2016). However, Nigeria is now struggling with the obligation of meeting self-sufficiency in terms of fish production.

Ozigbo, et al., (2014) posited that nutrition improvement especially in rural areas, revenue diversification, and employment creation remained the objectives of aquaculture development in Nigeria. Inrural communities, where opportunities for economic activities are limited, aquaculture activities are seen as the fulcrum of both youths and women empowerment. Recently, aquaculture has been viewed also as an activity that is very promising in terms of meeting the deficit in fish supplies, thereby curbing importation.

Although aquaculture production in Nigeria has experience rapid growth in recent years, the industry is still constrained by an inadequate feed supply. The poor quality local feeds currently used by the industry sparks mortalities, exacerbates low productivity and consequently result in low rate of return on investment (ROI). In the order hand, the prices of imported feeds are skyrocketing, fuelled by the current abrupt rise in exchange rate. From the foregoing, a viable aqua feed industry is needed for a sustainable aquaculture production in Nigeria.

Table 1. Aquaculture Production in Nigeria since.

\begin{tabular}{|l|l|l|l|l|l|}
\hline $\begin{array}{l}\text { YEA } \\
\mathbf{R}\end{array}$ & $\begin{array}{l}\text { Projected } \\
\text { Million) }\end{array}$ & $\begin{array}{l}\text { Population } \\
\text { (Tonnes) }\end{array}$ & Fish Demand & $\begin{array}{l}\text { Projected Domestic Fish Supply } \\
\text { (Tonnes) }\end{array}$ & $\begin{array}{l}\text { Deficit } \\
\text { (Tonnes) }\end{array}$ \\
\hline $\mathbf{2 0 0 0}$ & 114.40 & 1430.00 & 467.098 & 962.902 \\
\hline $\mathbf{2 0 0 1}$ & 117.60 & 1470.00 & 480.163 & 984.836 \\
\hline $\mathbf{2 0 0 2}$ & 121.00 & 1412.50 & 507.928 & 1004.572 \\
\hline $\mathbf{2 0 0 3}$ & 124.40 & 1555.00 & 522.628 & 1063.082 \\
\hline $\mathbf{2 0 0 4}$ & 128.00 & 1600.00 & 536.917 & 1063.072 \\
\hline $\mathbf{2 0 0 5}$ & 131.50 & 1643.75 & 552.433 & 1091.317 \\
\hline $\mathbf{2 0 0 6}$ & 135.30 & 1691.25 & 567.948 & 1123.307 \\
\hline $\mathbf{2 0 0 7}$ & 139.10 & 1732.75 & 585.872 & 1154.873 \\
\hline $\mathbf{2 0 0 8}$ & 143.00 & 1782.30 & 600.612 & 1186.887 \\
\hline $\mathbf{2 0 0 9}$ & 147.10 & 1838.75 & 617.353 & 1221.397 \\
\hline $\mathbf{2 0 1 0}$ & 151.20 & 1810.00 & 634.500 & 1255.440 \\
\hline $\mathbf{2 0 1 1}$ & 155.50 & 1943.75 & 652.606 & 1291.143 \\
\hline $\mathbf{2 0 1 2}$ & 160.00 & 2000.00 & 689.958 & 1328.508 \\
\hline $\mathbf{2 0 1 3}$ & 164.00 & 2113.75 & 709.683 & 1365.042 \\
\hline $\mathbf{2 0 1 4}$ & 169.10 & 2175.00 & 730.248 & 1404.067 \\
\hline $\mathbf{2 0 1 5}$ & 174.00 & 2055.00 & 671.493 & 1444.752 \\
\hline Source: $($ FDF, 2008) (Tonnes $\times \mathbf{1 0 0 0})$ & & \\
\hline
\end{tabular}

\section{StATUS OF Nigeria AQUA FEEDS INDUSTRY}

\subsection{Past Status of Aqua Feeds Industry}

According to UNCTAD/GATT (1984), total production of compound feed in Nigeria was estimated at around 800,000 tons in 1981, 600,000 tons in 1982 and 400,000 tons in 1983. The decline has been attributed to the serious domestic economic crisis then prevailing and its impact on the livestock sector. The approximate shares by feed type in total output during these years were as follows: Poultry feed, 90 percent, cattle feeds, 7 percent, feed for pigs and other animals, 3 percent. Production was projected at estimated 480,000 tons at end of 1984. By 1986 demand for compound feeds from industrial livestock farms (of which 90 percent will be commercial poultry operation) would climb to about 600,000 tons of poultry feeds and 90,000 tons of feed for pigs and other animals, or a total of 690,000 tons. During these years, the contribution of aqua feed to the total animal feed production 
was very negligible. It was grouped among the three percent contribution by pigs and other animals (Figure 1)

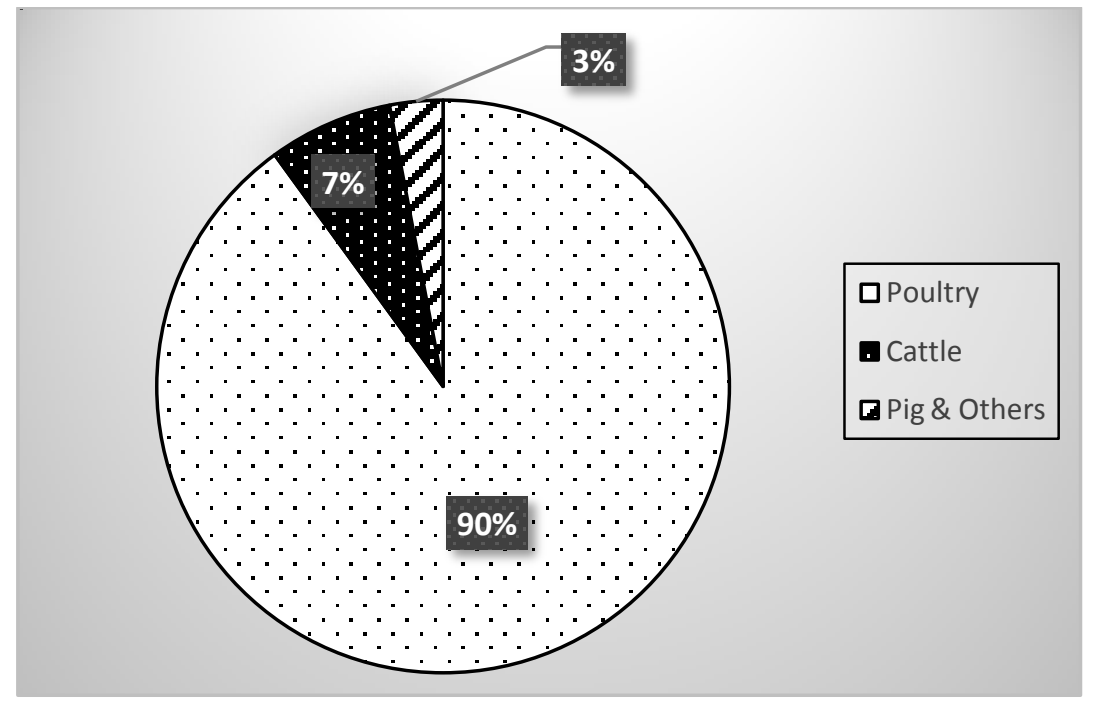

Figure 1. Nigeria's animal feed sector as at 1984 (Source: UNCTAD/GATT (1984)

Of the 350 feed mills registered in 1983, only 185 were operating in mid-1984. Their total production capacity was $1.2 \mathrm{Mt}$ of compound feed annually. Three companies accounted for about 50 percent of total production, plants integrated into large scale poultry production 20 percent and small plants with hourly capacity of up to 2.3 tons 30 percent (ibid.).

In 2000, an estimated 35,570 tonnesof feed were used by the Nigerian aquaculture industry (Fagbenro and Adebayo, 2005). This quantity still represented a negligible proportion $(<1$ percent $)$ of the national feed production. However, aquafeeds industry has started to gain recognition. A projection of future aquafeed requirements for 2015 suggests that at an annual growth rate of 10 percent, Nigeria would have the potential to produce sufficient aquafeeds using existing production capacity. The contribution of the Nigerian aquafeeds industry to the national feed production is presented on figure 2.

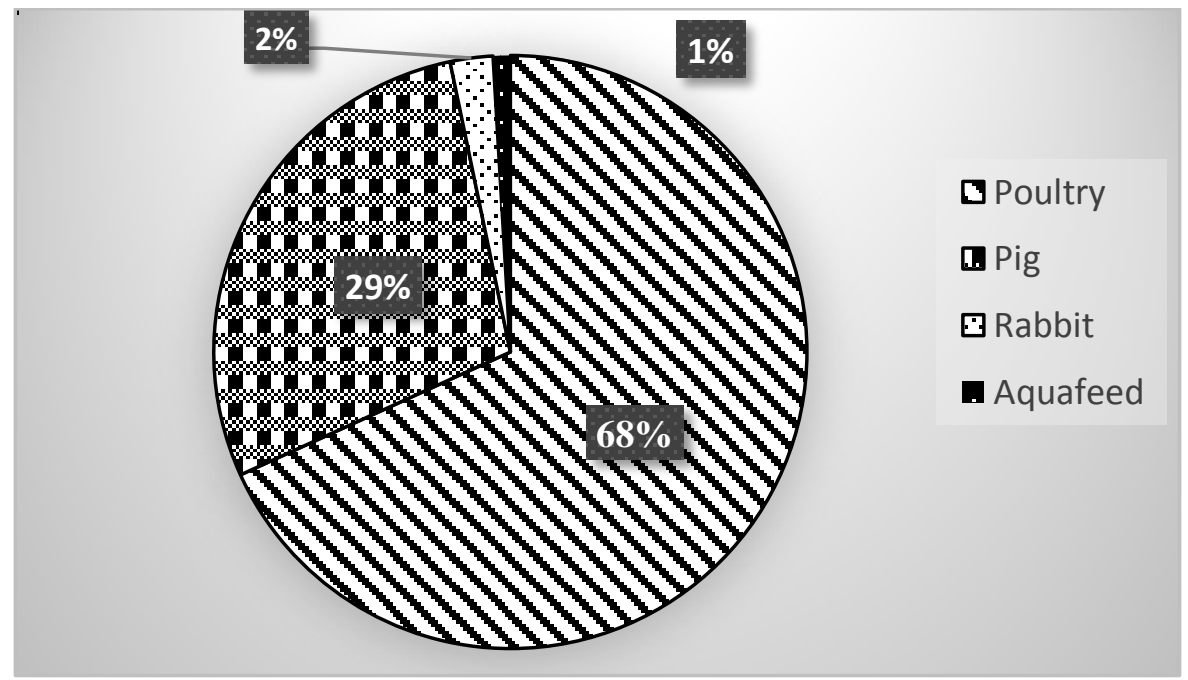

Figure 2. Nigeria's animal feed sector as at 2000 (Source: Fagbenro and Adebayo, 2005)

\subsection{Present Status of Aqua Feeds Industry}

Nigeria has significantly improved in the area of aqua feeds production between 2014 and 2015 . Nigeria is now rated as one of the largest emerging animals feeds producers in the world with the potentials for commercial production. In 2015 the Nigeria's animal feed sector has been rated as number 40th in the world; moving 11 steps forward from its previous ranking of number 51 among the 130 leading animal feeds producing countries in the world. Nigeria is estimated to have produced 3.8 million metric tons (MT) of animal feeds in 2014 and 5.3 million MT of animal feeds in 2015 with aquaculture contributing 12 percent second to poultry production (Figure 3 ). 


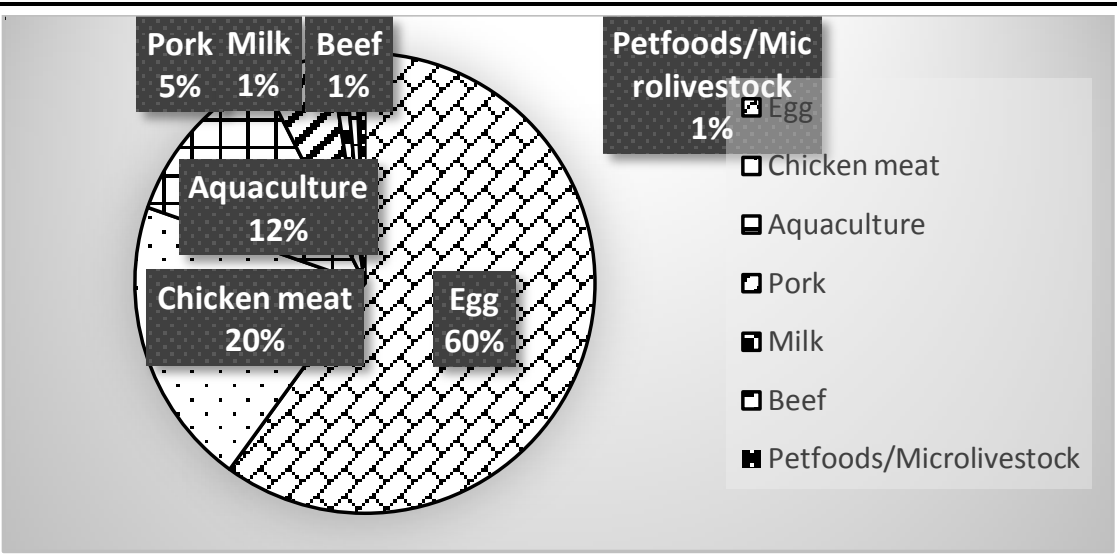

Figure 3. Nigeria's animal feed sector as at 2015 (Source: Alltech, 2016)

\section{Aqua Feed Supply Analysis}

In Nigeria, the aqua feed industry is dominated by few large commercial feed industries usually based in Europe, Asia or America who run local franchised industries. Currently, emphasis has been placed on encouraging indigenous feed enterprises that make use of local ingredient in formulating feeds for the fish industry. The task of meeting the increasing demand for fish feed can best be realized through increased availability of indigenous feed production. indigenous Feed Enterprises are seen as an honest approach because of ease of availability of raw materials, and access by fish farmers. Severalstrategies have been adopted such as price policies, input subsidies, production credit and liberalization by governments and individuals to increase the output of these fish feed enterprises, yet their performance is low in terms of meeting the needs of the fish industry. Interestingly, the request for the products of the enterprises is daily on the increase (EDR, 2014).Two types of aquafeeds are used to culture fish in Nigeria. According to Ibiyo and Olowosegun (2005), these are On-farm feed and commercial feed.

\subsection{On-Farm Aqua feeds.}

These are farm made feeds. According to Ibiyo and Olowosegun (2005), of the estimated total of 35,570 tons of aquafeed produced in year 2000 on-farm feed account for a whopping $70 \%$.On-farm feeds are usually made up of naïve feedstuffs fed as blended, doughs or compressed pellets (Shipton and Hassan, 2013). The quality of farm made aquafeeds depends on the method of formulation, ingredient quality, availability and affordability; and the processes of manufacture. In Nigeria, farm made aqua feeds are cheaper than commercial aquafeeds little wonder local farmers have preference for them. According to these authours, they remain the only option for semi-intensive farmers in Nigeria. Non-conventional feed ingredients are commonly used in on-farm aqua feed production in rural areas in Nigeria among low income group that are actively engaged in fish farming (Abowei and Ekubo, 2011) and most of these non-conventional ingredients have been evaluated (Udo and Umoren, 2011). According to Ogugua and Eyo (2007), the production quantity is not clear since it difficult to quantify.

\subsection{Commercial Aqua Feeds}

Commercially manufactured aqua feeds are feeds that are wontedly formulated to meet the nutritional requirements of a distinctive fish species and their different life stage. Two forms of commercial aquafeeds have been identified viz. locally manufactured and imported commercial feeds (Shipton and Hassan, 2013).

\subsubsection{Locally Manufactured Aqua feeds}

Currently, Nigeria is rapidly gaining access tolocally manufacturing capacity and consequently, many local feed millers are producing some fish feeds, viz. CHI, Grand Cereals for Vital Feeds and aquamax, Tempo Feed Mill for Fresh line Feeds and Durante (Gabriel et al., 2007) others are: MOSAB, Ideal Fish Feeds, Aqua Vista Feeds, Megatimex, UNIFACO, Aqua Plus, High Yield, Jib Feeds, Darrell Feeds, premier feed etc. (USAID, 2010) These companies offer compounding services (tolling) to farmers willing to self-formulate their feeds. According a survey by Alltech, (2017) Nigeria, among other African countries showed evidence of growth greater than an impressive 30 percent in 2016. 


\subsubsection{Imported Fish Feeds}

According to foraminifera market research, Nigeria import aqua feeds amounting to an estimated 75 percent of the total feed production. In a nutshell, Nigeria imports between 700,000 and 900,000 metric tons of fish annually. Imported feeds are all high quality floating feeds. Admittedly, small fish need high protein $(50 \% \mathrm{CP})$ and tiny pellets $(0.8-1.5 \mathrm{~mm})$ feeds that jumpstarts their growth. As most local aqua feeds only include the larger size pellets that are mostly of low crude protein content, fish farmers resort to imported starter feeds. Many fish farmers prefer using imported starter feeds throughout the nursery stage (1-2 months) before changing to the lower cost feeds (USAID, 2010) which most of the times are locally produced pellets. These imported smaller pellets are very expensive, but the high crude protein content boosts the growth of the young larvae and fry. Some imported aquafeeds used by fish farmers in Nigeria are presented in Table 2.

Nonetheless, current assessment of aquafeeds used by fish farmers in Nigeria showed that 33.3 percent of the fish farmers used both imported and local pelleted feeds, 26.7 percentused locallyproduced pelleted feeds, merely 20 percentused imported feeds only, 16.7 percent used other Nigerian feeds, while 3.3 percent used locally manufactured powdered feeds in feeding their fish (Obe and Omojola, 2015).

Table 2. Imported aquafeeds used by fish famers in Nigeria

\begin{tabular}{|l|l|l|l|}
\hline Brand name & Country imported from & Pellet type & Pellets size (mm) \\
\hline Coppens & Netherlands & Floating & $\begin{array}{l}0.2,0.3,0.5,0.8,1.2,1.5,2.0,3.0,4.5,6.0, \text { and } \\
8.0\end{array}$ \\
\hline Sharp & China & Floating & $0.2,0.3,0.6,0.85,1.2,1.5,2.0,3.0,5.0$ \\
\hline Raanan Feed & Isreal & Floating & $0.2,0.3,0.5,0.8,1.2,1.5,2.0,3.0,4.5,6.0$, and 8.0 \\
\hline Multifeed & Isreal & Floating & $0.2,0.6,1.1,1.4,2.0,3.0,4.0,6.0$, and 9.0 \\
\hline Zeigler & USA & Floating & $\leq 0.6,0.85,1.2,1.5,2.0,3.0,5.0$ \\
\hline SARB Gheerbrant & Germany & Floating & $0.2,0.6,1.1,1.4,2.0,3.0,4.0,6.0$, and 9.0 \\
\hline Skretting (France) & France & Floating & $0.2,0.6,1.1,1.4,2.0,3.0$ \\
\hline
\end{tabular}

Source: Authors, USAID 2010

\section{Challenges FaCing THE Nigerian AQUA FEEDS INDUSTRY}

The challenges faced by the Nigerian aqua feeds industry are presented in figure 4. Obe and Omojola, (2015) in their assessment posited that main challenge faced by the Nigerian aqua feeds industry is high cost of feed ingredients which constituting about 60 percent of the total challenges. The major ingredients in aqua feeds are fishmeal, soybeans and maize. Major diets ingredients include cereals, fats and oils, which serve as protein and energy sources in the aqua feeds. Indirect devaluation of the naira has also result in hike of raw material prices, particularly fishmeal, maize and soybean. Currently, maize production has been negatively affected by pest. These has resulted in a sudden jump in the prices of aqua feeds. According to Daily Trust of 20 October, 2016 the prices of fish feeds, have risen by up to 80 to 100 percent and many fish farmers have been compelled to leave the business especially in Lagos State.

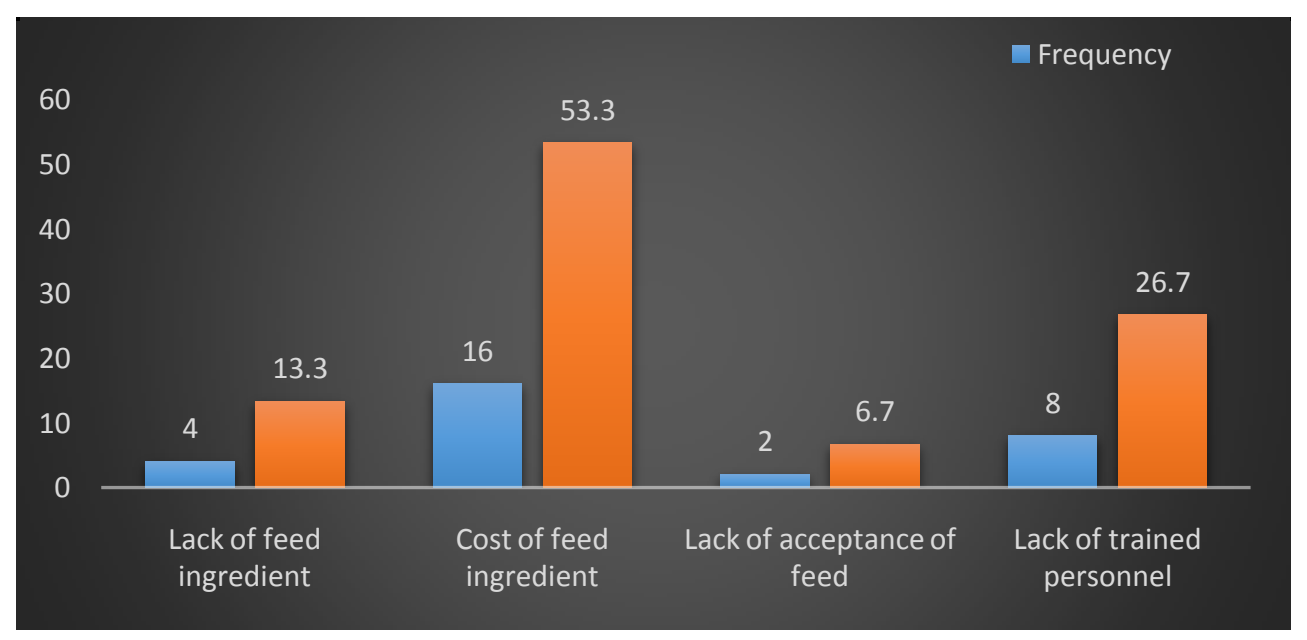

Figure 4. Challenges of the Nigerian Aquafeed Industry

Source: Obe and Omojola, (2015) 
Lack of trained personnel in areas of aquaculture nutrition, feed formulation and processing, and machine operators is second among the challenges constituting about 27 percent of the challenges. (Ogugua and Eyo 2007, Obe and Omojola, 2015)). For instance, fish feeds processed by extrusionexhibit floating characteristic of imported floating fish feed.Glaringly, extruded feeds are more cost effective than compressed pellets. It also exbhibits improved quality which resulted in increased profitability for both importers and fish farmers.

Lack of feed ingredients is the third in the list constituting about 14 percent of the challenges. The cause of unavailability of feed ingredient are suboptimal production of raw materials, animal and human increase competition for energy sources/conventional feed ingredients. "Poverty Syndrome" has led to unnecessary pressure being directed toward maize and soybean. For instance, maize is consumed by the poor Nigerians as ogi/akamu, tuwo, semovita etc. while soya is consumed as soya milk, soya puff, soya-iru, soya-egusi, soya meat, soya-garri etc. Continuous growth of Nigerian /Global population along side aquaculture also contribute to lack or shortage of feed ingredients. According to Shepherd and Jackson (2013), the estimated use of fishmeal by aquaculture is 75\% while crustaceans use the largest portion (29\%) as compared to other fish species. Current level of raw materials production does not meet the needs of both animal and aquafeeds industry and the nonconventional ingredients which could be used as substitutes have limitation in commercial quantity as well as localized availability. Seasonality results in inconsistency in availability and quality.

\section{Conclusion}

With the rapid growth of aquaculture, Nigeria has currently improved significantly in the area of aquafeeds production between 2014 and 2015. Nigeria is now rated as one of the world's largest newly independent aquafeeds producers with a better opportunity for commercialization. However, recent statistics show that currently up to 75 percent of the total aquafeeds used by fish farmers in the country is imported. The recent dwindling yield in grains production has also encouraged importation. To meet increasing demand for feeds ingredients, current national production will have to be beefed up and alternative sources exploited and commercialized. New methods of processing and formulation will also go a long way in increasing the chances of inclusion of the non-conventional ingredients into aquafeed. In order for the Nigerian aquafeeds industry to reach self-sufficiency, government should provide assistance for the agricultural sector by setting aside more money for people to do commercial agriculture. New methods of crop production should also be employed as this will go a long way in improving productivity of feed ingredients required to manufacture nutritionally balance and cost effective aquafeeds for great expansion of aquaculture in Nigeria.

\section{REFERENCES}

[1] Abowei, J. F. N. and Ekubo, A. T. (2011). A Review of Conventional and Unconventional Feeds in Fish Nutrition. British Journal of Pharmacology and Toxicology 2(4): 179- 191.

[2] Adedeji O. B. and Okocha, R. C. (2011) Constraint to Aquaculture Development in Nigeria and Way Forward. Veterinary Public Health and Preventive Medicine, University of Ibadan, Nigeria.

[3] Adekeye, O. A. (1976) Fish farming, solution to perennial protein shortage in Nigeria. Sunday Herald, Issue 19 January, 1986. p.7. Printed and Published by Kwara State Printing and Publishing Corporation, Ilorin,

[4] Alltech (2016). Alltech Global feed survey 2016.

[5] Alltech (2017). Alltech Global feed survey 2017

[6] Augood, C., Chakravarthy, U.,Young, I. Vioque, J., TVM de Jong, P.,Bentham, G.,Rahu, M.,Seland, J., Soubrane, G.,Tomazzoli, L.,Topouzis, F., Vingerling, J. R. and Fletcher, A. E. (2008). Oily fish consumption, dietary docosahexaenoic acid and eicosapentaenoic acid intakes, and associations with neovascular age-related macular degeneration.Am. J. Clin. Nutr. 88 (2) 398-406

[7] Bäärnhielm, M., Olsson, T., Alfredsson, L. (2014). Fatty fish intake is associated with decreased occurrence of multiple sclerosis. Mult. Scler. 20(6):726-32. doi: 10.1177/1352458513509508.

[8] CBN (2016), 2015 Statistical Bulletin: Domestic Production, Consumption and Prices. Central Bank of Nigeria Annual Statistical Bulletin https://www.cbn.gov.ng /Out/2016/SD/ 2015\% 20Statistical\%20Bulletin 
[9] Djoussé, L., Akinkuolie, A. O., Wu, J. H., Ding, E. L. and Gaziano, J. M. (2012).Fish consumption, omega-3 fatty acids and risk of heart failure: a meta-analysis. ClinNutr. 31(6):84653. doi: 10.1016/j.clnu.2012.05.010.

[10] EDR (2014). Analysis of Fish Feed Market in Delta State. Economic Development Research No 7. PIND Foundation. Pp 63.

[11] Fagbenro, O.A. and Adebayo, O.T. (2005). A review of the animal and aquafeed in Nigeria. In A synthesis of the formulated animal and aquafeed industry in Sub-Sahara Africa. CIFA Occasional Paper No 26 P2C 36.

[12] FAO (2012). Food and Agriculture Organization of the United Nations. The State of the World Fisheries and Aquaculture FAO, Rome Italy.

[13] FAO (2014). Food and Agriculture Organization of the United Nations. Inland Fisheries Resources of Nigeria. Corporate Document repository. Produced by Fisheries and Aquaculture Department. Accessed on 7th of March 2014 Available: http://www.fao.org/documents /en/detail/64969 .

[14] FDF (2008). Federal Department of Fisheries, Fisheries Statistics of Nigeria Projected human population; fish demand and supply in Nigeria, $2000-2015$ 56pp.

[15] Francis, A. and Davies, C. I (2014). Technology for the Culture of Marine Fish Species: Prospects and Implementation in Nigeria. Journal of Fisheries and Aquatic Science, 9: 288-293.

[16] Gabriel, U. U., Akinrotimi, O. A., Bekibele, D. N., Onunkwo, D. N. and Anyanulu, P. E. (2007). Locally Produced Fish Feed, Potentials for Aquaculture Development in Sub-Saharan. African Journal of Agriculture Research 297:287.

[17] Hallahan, B, Hibbeln, J. R., Davis, J. M. and Garland, M. R. (2007). Omega-3 fatty acid supplementation in patients with recurrent self-harm. Single-centre double-blind randomised controlled trial. Br. J. Psychiatry. 190:118-22.

[18] Hansen, A. L., Dahl, L., Olson, G., Thornton, D., Graff, I. E., Frøyland, L., Thayer, J. F., and Pallesen, S. (2014). Fish consumption, sleep, daily functioning, and heart rate variability. J. Clin. Sleep. Med. 10(5): 567-575. doi: 10.5664/jcsm.3714.

[19] Ibiyo, L.M.O. and Olowosegun, T. (2005) On-farm feed: the potential for improving profitability in aquaculture. In: 19th Annual Conference of the Fisheries Society of Nigeria (FISON), 29 Nov - 03 Dec 2004, Ilorin, Nigeria, pp. 45-53.

[20] Ita, E. O.; J. K. Balogun, A. Pandogari, B. Ibitoye and Sado, E. K. (1985). A preliminary checklist of inland water bodies in Nigeria with special reference to ponds, lakes, reservoirs and major rivers. Kainji Lake Research Institute Technical Report Series No.14.

[21] Jhingran, V. G. (2001). Introduction to aquaculture. United Nations Development Programme, Food and Agriculture Organization of the United Nations, Nigerian Institute for Oceanography and Marine Research.

[22] Lim, L. S., Mitchell, P., Seddon, J. M., Holz, F. G., Wong, T. Y. (2012). Age-related macular degeneration. Lancet. 5; 379 (9827):1728-38. doi: 10.1016/S0140-6736(12)60282-7.

[23] Little, D. C., Newton, R. W. and Beveridge, M. C. N. (2013). Aquaculture: a rapidly growing and significant source of sustainable food? Status, transitions and potentials. A conference paper on the future of animal products in the human diets: Health and environmental concerns. symposium 3: Alternatives to meat; organized by the Nutrition Society Summer meeting 2015 held at University of Nottingham on 6-9 July 2015.

[24] Löfvenborg, J. E., Andersson, T.,Carlsson, P. O., Dorkhan, M.,Groop, L., Martinell, M., Tuomi, T., Wolk, A. and Carlsson, S. (2014). Fatty fish consumption and risk of latent autoimmune diabetes in adults. Nutr Diabetes, 4(10): e139. doi:10.1038/nutd.2014.36

[25] Malesa-Ciećwierz M, Usydus Z. (2015). Vitamin D: can fish food-based solutions be used for reduction of vitamin D deficiency in Poland? Nutrition 31(1):187-92. doi: 10.1016 /j.nut .2014.07.003.

[26] Ngueku, B. B. (2015). Cultivable fish species of river awe, Nasarawa State, Nigeria. International Journal of Fauna and Biological Studies 2 (2): 15-19

[27] Obe, B. W. and Omojola, F. E. (2015). Assessment of Fish Feeds Used in Fish Farms in AdoEkiti, Nigeria and Effects on Fish Production. Journal of Biology, Agriculture and Healthcare. 5(2) 181-186. 
[28] Ogugua, N. M. and Eyo, J. E. (2007). Finfish feed technology in Nigeria. J. Res. Biosci., 3: 2339.

[29] Olagunju, F. I., Adesiyan, I. O., and Ezekiel, A. A. (2007). Economic viability of Catfish production in Oyo state, Nigeria. J. Hum. Ecol; 21(2):121-124.

[30] Ozigbo, E., Anyadike, C., Adegbite, O. and Kolawole P. (2014). Review of Aquaculture Production and Management in Nigeria. American Journal of Experimental Agriculture 4(10): 1137-1151.

[31] Raji, C. A., Erickson, K. I., Lopez, O. L., Kuller, L. H., Gach, H. M., Thompson, P. M., Riverol, M. and Becker. J. T. (2014). Regular fish consumption and age-related brain gray matter loss. Am. J. Prev. Med. ; 47(4):444-51. doi: 10.1016/j.amepre.2014.05.037.

[32] Ruxton, C. H. S., Reed, S. C., Simpson, M. J. A., Millington, K. J. (2004). The health benefits of omega-3 polyunsaturated fatty acids: a review of the evidence. Journal of Human Nutrition and Dietetics, 17(5):449-459.

[33] Shepherd, C. J. and Jackson, A. J. (2013). Global fishmeal and fish oil supply - inputs, outputs, and markets. $6^{\text {th }}$ World Fisheries Congress, Edinburgh 2012. International Fishmeal \& Fish Oil Organisation www.iffo.net

[34] Shipton, T. A. and Hasan, M. R. (2013). An overview of the current status of feed management practices. In M.R. Hasan and M.B. New, eds. On-farm feeding and feed management in aquaculture. FAO Fisheries and Aquaculture Technical Paper No. 583. Rome, FAO. pp. 3-20.

[35] Udo, I. U. and Umoren, U. E. (2011). Nutritional Evaluation of some Locally Available Ingredients Use for Least-Cost Ration Formulation for African Catfish (Clarias gariepinus) in Nigeria. Asian Journal of Agricultural Research, 5:164-175.

[36] UNCTAD/GATT (1984). Animal Feed Ingredients. A study of selected markets. International Trade Center, UNCTAD/GATT, Geneva. Published by the government of Netherlands, pp 241.

[37] USAID (2010) “Aquaculture Buyer's Guide, United States Agency for International Development.

[38] World Bank (2013). Fish to 2030. Prospect for Fisheries and Aquaculture, Agriculture and Environmental Services Discussion Paper number 3. Washington DC. World Bank Group.

[39] Yang, H. Xun, P., and He, K. (2013). Fish and Fish Oil Intake in Relation to Risk of Asthma: A Systematic Review and Meta-Analysis. PLoS One 8(11): e80048. doi: 10.1371/journal. pone. 0080048 . 